
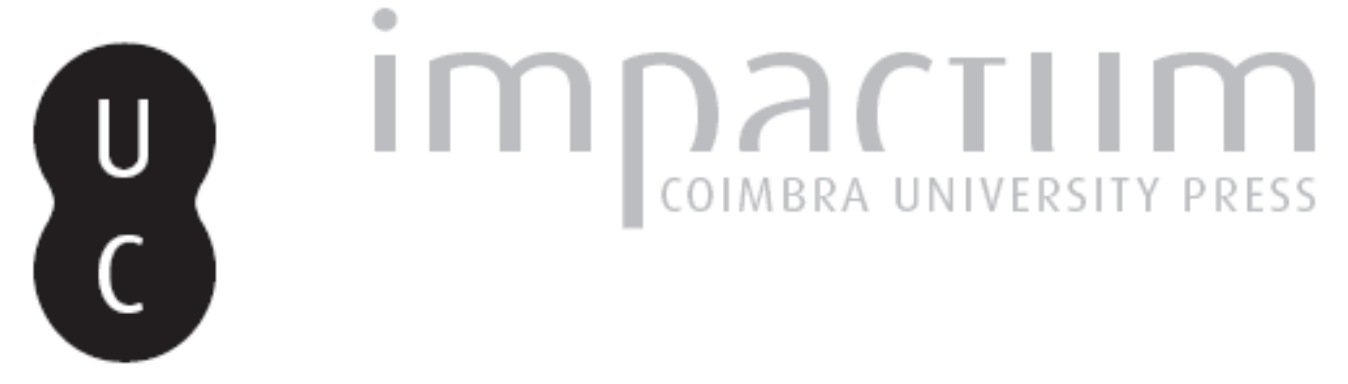

\title{
Estado actual da investigação da história jurídica moderna em Espanha e Portugal
}

Autor(es): $\quad$ Scholz, Johannes-Michael

Publicado por: Imprensa da Universidade de Coimbra

URL persistente:

URI:http://hdl.handle.net/10316.2/43930

DOI:

DOI:https://doi.org/10.14195/2183-8925_3_6

Accessed : $\quad$ 26-Apr-2023 03:43:05

A navegação consulta e descarregamento dos títulos inseridos nas Bibliotecas Digitais UC Digitalis, UC Pombalina e UC Impactum, pressupõem a aceitação plena e sem reservas dos Termos e Condições de Uso destas Bibliotecas Digitais, disponíveis em https://digitalis.uc.pt/pt-pt/termos.

Conforme exposto nos referidos Termos e Condições de Uso, o descarregamento de títulos de acesso restrito requer uma licença válida de autorização devendo o utilizador aceder ao(s) documento(s) a partir de um endereço de IP da instituição detentora da supramencionada licença.

Ao utilizador é apenas permitido o descarregamento para uso pessoal, pelo que o emprego do(s) título(s) descarregado(s) para outro fim, designadamente comercial, carece de autorização do respetivo autor ou editor da obra.

Na medida em que todas as obras da UC Digitalis se encontram protegidas pelo Código do Direito de Autor e Direitos Conexos e demais legislação aplicável, toda a cópia, parcial ou total, deste documento, nos casos em que é legalmente admitida, deverá conter ou fazer-se acompanhar por este aviso.

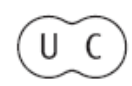




\section{REVISTA DE HISTORIA DAS IDEIAS}

Volume III

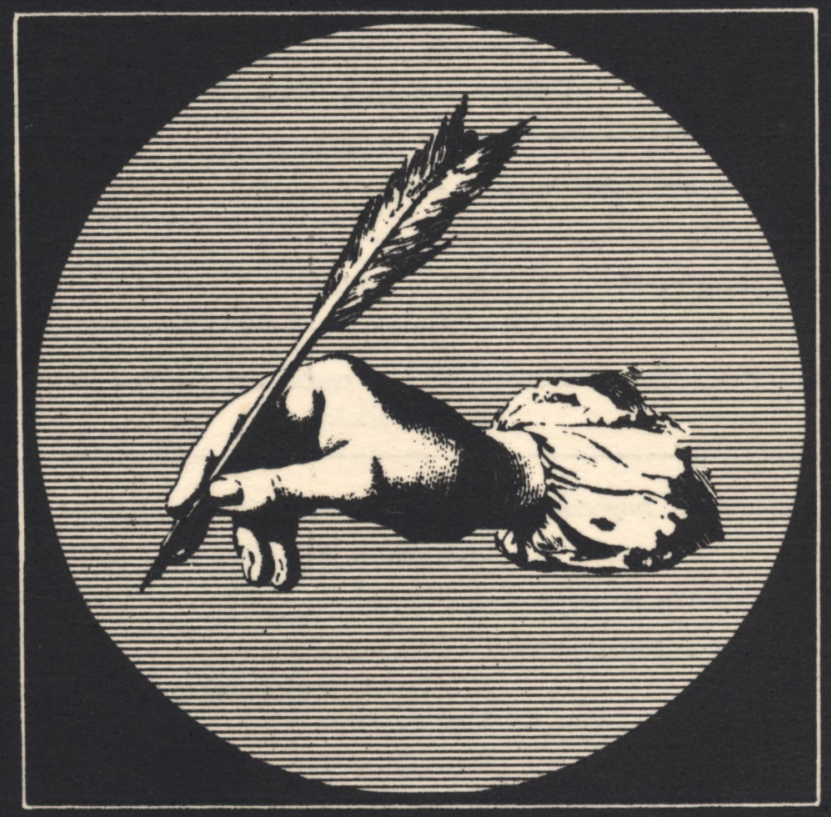

INSTITUTO DE HISTÓRIA E TEORIA DAS IDEIAS

$$
\begin{gathered}
\text { FACULDADE DE LETRAS } \\
\text { COIMBRA } 1981
\end{gathered}
$$




\section{ESTADO ACTUAL DA INVESTIGAÇÃO DA HISTÓRIA JURÍDICA MODERNA EM ESPANHA E PORTUGAL}

1. Ius commune; 2. Direitos particulares; 3. Estado de direito burguês.

Os panoramas bibliográficos ressentem-se normalmente de pretenderem uma aparência de objectividade. Quando o facto é que, na maior parte dos casos, eles dizem mais sobre o seu autor do que sobre o objecto descrito. Exemplares são, nesta medida, os conspectos de Arnaud (1) sobre os mais recentes resultados da investigação fundamental no domínio da ciência do direito em Itália, uma vez que eles não deixam à partida lugar a qualquer dúvida sobre a intensidade da ligação entre os interesses gnoseológicos pessoais do autor e os critérios de selecção. Isto é ainda mais válido no nosso caso, pois a cooperação no processo de investigação implica necessariamente uma certa tomada de partido; e, com isto, um aumento do tisco de parcialidade.

Quem toma partido contra uma história jurídica narcisista e a favor de uma história do direito ao serviço do presente (2), constata com alegria que tanto em Espanha como em Portugal parece ter-se atingido finalmente um momento de ruptura. Ainda nos finais da década de sessenta o monopólio de uma medievística com o centro em Espanha parecia pouco abalado. E como a história jurídica das épocas mais recentes estava, em princípio, excluida, estava-o também

(1) Cf. A.-J. Arnaud, Italiennes, I-III, em «Archives de phil. du droit» (Paris), 18 (1973) 311-22; 21 (1976) 231-8; 24 (1979) 467-475.

(2) Cf. J.-M. Scholz, Historische Rechtsgeschichte, em J.-M. Scholz (ed.) "Vorstudien zum Rechtshistorik», Frankfurt/Main 1977, p. 1-175. 
qualquer análise relacionada com o presente (1). Tal como Garcia-Gallo já suspeitava em 1974, o que ocorreu nos anos setenta foi uma reorientação global da disciplina, tanto no que diz respeito à historiografia jurídica espanhola, como no relativo à hispano-americana, por ela fortemente influenciada (2). O que já hoje se torna patente - e com isto, Garcia-Gallo não corria, pela sua parte, o risco de estar de acordo é o fim de uma era Garcia-Gallo de quase quarenta anos (3). Depois da morte de Merêa e de Braga da Cruz (1977), também em Portugal se dissolve uma comunidade de contactos científicos que durou muitos anos e no centro da qual estava também, decerto modo, Garcia-Gallo. Sinal de tudo isto é a polémica a que este autor se vê exposto e a que procura responder com a ajuda do seu «Anuario» $\left({ }^{4}\right)(5)$. Mesmo se actualmente, em Portugal, os representantes da concepção tradicional da história jurídica se reinstalam, a utilização de apoios alemães na defesa contra a reflexão histórico-jurídica dos historiadores do direito sobre a sua própria investigação e contra a actual ciência historiográfica revela, aparentemente, insegurança metodológica, quando não um certo desamparo (6).

(1) Cf. J. Lalinde Abadia, La dernière décennie dans l'historiographie juridique espagnole, em "Anuales de la Faculté de droit et de sciences économiques de Toulouse», 18, 1-2 (1970) 365-77.

(2) A. Garcia-Gallo, Cuestiones de historiografia juridica, em AHDE (Madrid) 44 (1974) 741-2.

(3) Cf., em especial, Garcia-Gallo, Metodologia de la historia del derecho indiano, Santiago de Chile 1970.

(4) Cf., sobre o papel central de Garcia-Gallo, F. Tomás y Valiente, La historiografia juridica en la Europa continental (1900-1975), em «Historia-Instituciones-Documentos» (Sevilha) 5 (1978) 463 e BeATrIz BuRnAL DE BugedA, Historiografia juridica hispano-americana en el siglo $X X$, em «LXXV anos de evolución jurídica en el mundo" (ed. Universidad Nacional Autónoma de México), II, México 1979, p. 60.

(5) Cf. os ataques visando directamente Garcia-Gallo de J. M. Perez PrenDES (Curso de historia del derecho español, I, Madrid 19788) e a réplica do co-editor dos AHDE em «AHDE» 47 (1977) 913; o controverso prólogo de M. PESET a A. Perez Martin e J.-M. Scholz, Legislación y jurisprudencia en la Espana del antiguo regimen, Valencia 1978, e a resposta oficial de A. D'ORS em "AHDE» 48 (1978) 761-3; e a recensão dos "Vorstudien...» (n. 2) por G. Villapalos, onde o meu trabalho é falsamente descrito como uma apologia de uma história do direito historicamente orientada no sentido de Garcia-Gallo, ao mesmo tempo que é silenciada a crítica dos irmãos Peset a Garcia-Gallo («AHDE» 47 (1977) 886-888).

(6) Cf. HANS THIEME, L'histoire du droit et la science juridique, em «História do direito e ciência jurídica. Homenagem póstuma a Braga da Cruz» (ed. Fundação Eng. ${ }^{\circ}$ António de Almeida), Porto 1977, 55-80. 
Sinais indesmentiveis da dissolução das estruturas habituais são os recentemente publicados Manual de história del derecho español (Madrid 1979) de F. Tomás y Valiente e História das instituições (Lisboa 1978-1980) de A. M. Hespanha.

É serto que voltavam a aparecer, nos anos setenta, conhecidos manuais escolares, muitas vezes confundidos fora da península com o todo da investigação histórico-jurídica destes países: em Espanha, - Curso de Galo Sanchez (Madrid 197210), a Historia general del derecho español (Madrid 19772) de GiberT e, antes de todos, o Manual de historia del derecho español (Madrid 19776/7), de Garcia-Gallo; em Portugal, o manual de Almeida Costa, Apontamentos de História do direito português (Lisboa 1979), seguindo de perto as liçð̃es de Braga da Cruz de 1955, completadas com alguns contributos pessoais. Também se verificaram nos últimos tempos essencialmente quatro tentativas notáveis, na tradição de um Eduardo Hinojosa, de apoiar o ensino do direito com material didáctico e de dar à investigação novos impulsos: a Iniciacion historica al derecho español (Barcelona 19701, 19782), de J. LALINDE ABADiA, obra a destacar no que respeita a originalidade, informação e abertura aos contextos chamados «extra-jurídicos» e que se seguiu, quantro anos depois, à sua comparativamente sintética exposição Derecho histórico español; o Curso de historia del derecho español (Madrid 19721, 1978²) de J. M. Perez-Prendes - uma obra sedutora do ponto de vista das novidades metodológicas, mas que, ao contrário da Iniciacion de Lalinde, não abrange a época moderna; a História do direito port uguês (Lisboa 1971), de N. J. EsPINOSA GoMES DA SiLva, de que saiu uma nova edição muito reelaborada (1980) e. finalmente, a História das instituições (Lisboa 1978-9, incompleta) de M. De Albuquerque.

Não obstante, cabe tanto aos trabalhos de Tomás y Valiente como de Hespanha uma importância a nosso ver maior na perspectiva de uma história do direito orientada para a focagem da história social, sensível às questð̃es metodológicas e aberta à moderna problemática. Eles conseguiram, nomeadamente, impor novos conceitos às concepções metodológicas canonizadas em não pequena medida pelos manuais inicialmente referidos. Na perspectiva aqui adoptada, interessa antes de mais o facto de à história pós-medieval do direito ser atribuido pela primeira vez um peso decisivo. No caso da Espanha, os Temas de historia del derecho, recentemente editados por historiadores do direito 
de Sevilha e destinados aos estudantes, podem também concorrer neste sentido; sobre isto daremos mais detalhes seguidamente.

Uma outra característica, ao lado da já referida deslocação do centro de gravidade temporal, e na verdade ainda mais decisiva do que esta «superación del medievalismo» (ToMÁs Y VALIENTE, p. 66), é a contínua compreensão da história do direito como história social. HesPANHA define este tipo de história do direito como a que se centra na questão: «como funciona sociologicamente... o direito» (p. 56); TомÁs Y VALIENTE concebe-a como o estudo da «formação do direito» e da «história das instituições», sem limitar esta última a uma descrição tecnicista que, portanto, desconhecesse o conteúdo social contemporâneo e que, nesta medida, renunciasse à explicação (p. 25-31).

Com isto é traduzida para o nosso campo de observação a querela metodológica dos últimos anos, aqui subjacente. É sintomático que, sobre ela, o órgão oficial dos historiadores espanhóis do direito, o "Anuario de historia del derecho», não nos dê informações senão insuficientes, no melhor dos casos indirectas, a maior parte das vezes unilaterais. A oposição metodológica exprime-se antes noutros lugares. De acordo com o referido órgão porta-voz dos representantes da linha historiográfica mais tradicional estar-se-ia obrigado a continuar a subscrever as concepções histórico-metodológicas que vêm sendo formuladas desde os anos cinquenta por Garcia-Gallo (1), o qual teria superado as orientações historiográficas do período anterior à guerra. O que é certo é que esta conclusão só é possível se se esquecerem factos fundamentaisc, omo os estragos da guerra, a morte de Riaza, ou a emigração de Altamira, de Ots e de Sanchez Albornoz. A intervenção GARCIA-Gallo a favor de uma história do direito sem conexóes com a ciência do direito ou com a ciência histórica baseava-se, segundo as suas próprias palavras, no crescente desinteresse de qualquer das duas disciplinas pela problemática histórico-jurídica. As oportunidades profissionais de sucesso dos historiadores do direito foram decerto favorecidas por esta autonomia da história do direito no plano da política científica. Mas esta situação de isolamento, aceite como inevitável, constituiu uma catástrofe para a história do direito.

(1) A. Garcia-Gallo, Historia, derecho y historia del derecho, em "AHDE» 23.1 (1953) 5-36. 
Neste contexto, interessa ter em conta a recusa - primeiro expressa, mais tarde (1) retocada de forma insignificante mas, na verdade, totalmente mantida nos seus efeitos - de novos métodos histórico-científicos, como os que a escola dos «Annales» antes exercitara e que tinham encontrado em Vicens Vives um seguidor contemporâneo na Espanha (2). $\mathrm{Na}$ medida em que faz a apologia de uma história do direito como "ciência jurídica», GaRCIA-Gallo privilegia as instituições com uma pretensa permanência jurídica ; mas, por outro lado, provoca - consequentemente - o seu afastamento em relação à chamada dogmática contemporânea; como consequência de tudo isto, verifica-se mais uma recusa da história jurídica moderna. Assim, o seu «método institucional» abandona os desenvolvimentos modernos do direito a uma tecnologia a-histórica. Esta inconsequência torna evidente, de forma involuntária, a função sócio-política das suas opç̃es metodológicas. $\mathrm{Na}$ medida em que furta o direito vigente à história do direito e, assim, o subtrai à crítica histórica, ele fortalece o sistema político, tanto mais quanto é certo que entrega, para efeitos de segurança, a discussão histórica do direito actual a uma jurisprudência escrava das normas, em face da qual tal direito está a salvo da crítica. É nesta linha que se orienta a historiografia jurídica ainda hoje dominante em Espanha. A este propósito são menos de recordar anteriores elogios de Martinez Gijón e Escudero do que a hiper-acentuação do texto jurídico por Gibert e d'Ors, sobretudo porque qualquer dos dois não recomenda a aplicação das modernas técnicas de análise textual (3).

Correcçð̃es do mesmo sentido tiveram forçosamente que ser introduzidas no domínio das relações entre direito e história. Aqui, o grande mérito cabe a LALINDE que, com o seu projecto de uma história

(1) Cf., v.g., a adesão contrariada de GarCia-Gallo às posições de Paradisi, «AHDE» 44 (1974) 742 ss.

(2) Cf. M. e J. L. PeSET, Vicens Vives y la historiografia del derecho en España, em J.-M. Scholz (ed.) «Vorstudien...» cit., 176-262.

(3) Cf. J. MARTINez Guón, Ante una nueva exposición de conjunto de la historia del derecho español "AHDE» 32 (1962) 581-94; J. A. EsCUDERO, En torno al objecto de la historia del derecho español, «AHDE» 32 (1962) 581-594; J. A. EscUDERo, En torno al objecto de la historia del derecho (1969), em Escudero, Historia del derecho - historiografia y problemas, Madrid 1973, p. 15-65; R. GiberT, Historia general del derecho español, Granada 1974, p. 6 ss. e, em pormenor, R. GiBERT, El funcionario español de la epoca austriaca, Madrid 1970, p. 6-7; A d'Ors, Sobre historiografia juridica, «AHDE» 47 (1977) 799 ss. (806 ss.). 
do direito como história do pensamento jurídico, se colocou muito perto de Wieacker, sendo imediatamente criticado por d'Ors como partidário do «sociologismo materialista», em virtude da sua abertura ao contexto histórico (1). Semelhante é a posição de Perez-Prendes que, a partir dos seus fundamentos fenomenológicos, concebe a dogmática jurídica como uma estrutura fechada, embora dependente do tempo e do contexto social, se bem que peque ainda pela costumada falta de comprovação das suas opiniōes em face da história jurídica mais moderna (2). Aqui reside a força de Tomás Y VALIENTE, que concebe o direito como produto - embora não redutível - do tempo e do espaço, no que é apoiado por De Dios através da questão da função do direito nas distintas sociedades históricas (3).

A crítica mais radical do programa de Garcia-Gallo é feita por Peset (4). Este estava legitimado para isto - tal como Tomás y Valiente e Clavero, de que se falará seguidamente - pelos seus vários estudos de detalhe. Numa análise muito fina, em parte histórico-científica, em parte sócio-política, confronta aquela «solución jurisdicista» de Garcia-Gallo com as virtualidades de uma história económica e social do tipo das de Vicens Vives e de Dominguez Ortiz, história que o positivismo jurídico, na esteira de Garcia Gallo, tinha recusado. Juntamente com seu irmão, um historiador da medicina, ele documenta pormenorizadamente quais as opçz̃es erradas que teriam impedido explicar o direito como uma realidade social: a perda de contacto com o direito vigente em favor de uma medievística em parte ainda dile-

(1) Cf. d'Ors, ibd., 806 n. 8; J. LALinde Abadia, Anotaciones historicistas al jusprivatismo de la segunda escolastica, em «La seconda escolastica nella formazione del diritto privato moderno», Milano 1973, p. 303; Apuntes sobre las «Ideologias» en el derecho historico español, «AHDE» 45 (1975) 123 ss.; Notas sobre el papel de las fuerzas politicas y sociales en el desarollo de los sistemas iushistóricos españoles («AHDE» 48 (1978) 249 ss.).

(2) Cf., ao lado do seu "Curso» (19788), em especial, Perez-Prendes, Notas para una epistemologia histórico-jurídica («Rev. hist. del der.» (Granada) 1 (1976) 269 ss.).

(3) Tomás y Valiente, Historia del derecho y historia, em «Onze ensayos de historia». Madrid 1976, 159-81; Historiografia jurídica (n. 6); Manual de historia del derecho español, Madrid 1979; S. DE Dios, El derecho y la realidad social. Reflexiones en torno a la historia de las instituciones («HID» 3 (1976) 189-222 (217 ss.).

(4) Peset/Peset: Vicens cit.; prefácio a Perez Martin/Scholz, Legislación y jurisprudencia cit.; M. Peset/J. Gutierrez Cuadrado/J. Trencho Odena, Fuero de Ubeda, Valencia 1979. 
tante e prejudicial à história jurídica moderna, a reserva em relação a estudos arquivísticos mais compreensivos em virtude de uma paixão pelo texto da lei, o mal entendido - no plano pedagógico e da estratégia da investigação - que leva a conceber o manual como um tratado científico, e a identificação errada da lei com o direito. Principalmente a última, ou seja, a contínua hipostasiação do direito positivo - faz com que Peset tome posição a favor de uma historiografia jurídica que utilize técnicas histórico-científicas e que, portan1o, produza resultados em que todos os dados sócio-económicos estejam presentes.

As preocupações metodológicas do historiador português do direito, HESPANHA, são semelhantes quanto aos seus pontos de partida (1). Para a sua posição contribui de forma essencial o seu juízo positivo acerca da "École des Annales», ou seja da escola histórica presentemente de ponta no contexto europeu. A história do direito de Hespanha (história social do direito/história das instituiçơes) não parte, por conseguinte, da concepção, insuflada pelo modelo liberal de Estado de direito, da identificação do direito com a lei. Interessam-lhe fundamentalmente os momentos de formação do direito, no plano das opções judiciárias, administrativas, doutrinais e da literatura jurídica vulgar. Ao contrário do que pretenderia uma história jurídica «événementielle», as obras dos coriféus jurídicos concorreriam com autores eventualmente de segundo plano. Para ele, a problemática social e os conflitos políticos condicionam o direito vigente. Isto não se opera, todavia, com a dissolução da esfera do direito numa história total. $\mathrm{Na}$ esteira de uma dialéctica de tipo althusseriano, é para ele a praxis jurídica quem explica a forma específica de funcionamento do aparelho jurídico, na sua totalidade, no conjunto global da história. Quem, como Hespanha, se ocupa da função social do direito, consegue transformar a história do direito numa introdução crítica ao direito hoje vigente ou, dizendo-o brevemente, legitimar a história do direito no seio do ensino jurídico.

(1) A. M. Hespanha, Análise do discurso e história da ciência juridica. Introdução metodológica a um tema de direito romano, Coimbra 1970; $O$ direito e a história. Os caminhos de uma história renovada das realidades juridicas («Rev. dir. est. soc.» (Coimbra) 17 (1971) 7-69; A história do direito na história social, Lisboa 1979; Curso de história das instituições, I, Lisboa 1978, 3-80. 
De modo semelhante a Peset e Hespanha, também Clavero (1) aproveita a problemática da historicização para com ela produzir, na verdade de forma ainda mais decidida, uma ciência alternativa do direito, empresa cuja necessidade é ilustrada por um recentíssimo manual de direito civil espanhol que, dando indicações de tipo histórico-jurídico, despreza por exemplo na apreciação do discurso da codificação o contexto histórico-sociológico da época, em última análise por motivos actuais de política do direito (2). É sobretudo nas últimas reflexões metodológicas de Clavero que se torna claro o que ele já desde há anos propugna: uma "ciência jurídica integral» (p. 51). Nela, caberia aos conhecimentos histórico-jurídicos um papel chave, pois eles constituiriam, caso fossem objecto de um tratamento histórico consequente, um seguro instrumento de orientação. Deste modo, a política do direito transforma-se em crítica da sociedade; para o que a historiografia do direito deveria levar a cabo a explicação de todas as ordens normativas, sem o que, tal como a tradicional história dos dogmas, acabaria por falhar na teorização sociológica. Em vez de se dissipar numa história total descomprometida (Perez Prendes), o objectivo é uma "virtual ciencia histórica del derecho» (p. 46), explorando o espaço social global. Ao libertar - como o teórico italiano das ciências sociais, Cerroni - a ciência jurídica da especulação e da apologética graças a uma história jurídica orientada verdadeiramente para a história, Clavero dá à história do direito a sua razão de existir e mostra com isto aos historiadores espanhóis do direito uma orientação que desemboca na sua participação numa teoria da sociedade crítica dos valores estabelecidos. Nesta medida, ele apoia - e disto está consciente - as propostas análogas, embora realizadas por vias diversas - de Wietholter e do autor (3).

As diferenças metodológicas indicadas, tal como se manifestam epigramaticamente nos títulos opostos dos programas de Garcia Gallo e de Clavero, mostram só por si a falta de identidade dos trabalhos

(1) B. Clavero, La historia del derecho ante la historia social («HID» 1 (1974) 239-61); mas sobretudo, Historia, ciencia, politica del derecho («Quaderni fiorentini per la storia del pensiero giuridico moderno »(Firenze) 8 (1980).

(2) Cf. a minha crítica a J. L. DE LOS Mozos (Derecho civil espanol, I 1, Salamanca 1977, maxime 227 ss.; em H. CoING (ed.), Handbuch der Quellen und Literatur der neueren europäischen Privatrechsgeschichte, III 1, Munchen 1980.

(3) Cf. Scholz, Historische Rechtshistorie, cit., maxime 168 ss. 
que vão ser indicados. As divergências aparecem por todo o lado. Assim, a discussão acerca de uma reforma do ensino histórico-jurídico fornece compreensivelmente o ensejo de confrontar as opinið̌es. Não apenas para - como o fez d'Ors numa oportunidade semelhantes denunciar os adversários como anti-cristãos e marxistas e para desqualificar a proposta de Tomás Valiente de investigar a história do direito do séc. XIX como uma forma de comodismo intelectual, aproveitando, por fim, para jurar fidelidade unica e exclusiva a Garcia-Gallo (1). Tais pretensões de excluir os adversários provocaram reacções de sinal contrário, a tal ponto que a história do direito estabelecida, dominada durante anos pelo "Instituto Nacional de Estudios Jurídicos», teve que aceitar confrontos aqui e ali. Sinais disto são constituídos pelas duas recentes revistas de história do direito de Granada e de Sevilha. Só a sua abertura esclarecida em relação às histórias social e económica assinala já uma ruptura com a tradição. E, de forma semelhante, é também eloquente que hoje se possam enumerar, além de Madrid, outros centros activos de pesquisa, nomeadamente no domínio que aqui nos interessa, como Sevilha, Valencia, Salamanca, Barcelona/ Zaragoza.

A situação portuguesa, em contrapartida, é de evolução mais difícil em virtude do imobilismo político de muitos anos. Aqui, o ponto de partida para os interessados é o «Instituto juridico da Faculdade de Direito» de Coimbra. Aproveite-se a oportunidade para referir a Biblioteca do «Max-Planck-Institut fur europäische Rechtsgeschichte» em Frankfurt am Main, que fora de Portugal e da Espanha, é o centro melhor equipado para a investigação no domínio da história jurídica moderna dos dois países.

A comodidade da pesquisa no domínio histórico jurídico está seguramente facilitada pela existência de uma série de trabalhos de natureza bibliográfica, de análises introdutórias ou de iniciações a questões de história jurídica. Do ponto de vista teórico, colocou-se com isto a primeira pedra para assegurar à história jurídica moderna de Espanha e Portugal o interesse que ela merece no domínio da investigação.

(1) Cf. (Ministerio de Educación y Ciencia, ed.), El primer ano de derecho. Actas de las jornadas de professores del primer ano de la Facultad de Derecho de la Universidad de la Rábida, Madrid 1978, e a crítica e esta publicação por A. d'ORS («AHDE» 48 (1978) 577-84). 
Pense-se a este propósito nas colecçð̃es de fontes legislativas e nas recolhas da respectiva literatura secundária, tal como foram elaboradas para o antigo regime espanhol e para o séc. xix por A. Perez Martin, Lasso GaITe e pelo Autor (1); no que respeita a Portugal, seja permitida uma referência aos trabalhos do próprio Autor (2) que se estendem também à jurisprudência de ambos os países (3). Para a ciência jurídica dos sécs. XVI a XVIII, a bibliografia raisonnée de HoLTHöFER presta um bom serviço (4). O Autor prepara actualmente uma introdução à literatura científica do séc. xIX, que abrangerá tanto a Espanha como Portugal. Ao lado desta, é de mencionar a bibliografia, até agora só parcialmente publicada, de Hespanha (5), Finalmente, e graças a A. Perez Martin, dispor-se-á dentro de poucos anos de um roteiro bibliográfico da história jurídica espanhola, a aparecer sob o título «História del derecho espanol».

Antes de se falar dos trabalhos mais importantes sobre o direito comum, os direitos particulares e o direito do Estado liberal, refiram-se alguns estudos político-institucionais. A não homogeneidade que um

(1) Cf. Pérez-Martín, La legislación de antiguo régimen, em Perez Martin/ SchOLz, Legislación y jurisprudencia, cit., 7-276; (J. F. LASSO GAITE), Crónica de la codificación (Ministerio de Justicia. Comissión General de Codificación), I. Organización judical; II. Procedimiento civil; III. Procedimiento penal; IV. 1-2. Codificación civil (Genesis y historia del Codigo), Madrid 1970-1979 (1980); ScHoLz, (Spanische Privatechts-, Zivilprozess- und Handelsprozessgestzgebung des 19. Jahrhunderts) em H. CoING (ed.), Handbuch (n. 19), III 1, Munchen 1981, e III. 2, Munchen 1981.

(2) Scholz, (Portugiesische Gesetzgebung des 16.-18. Jahrhunderts) em H. CoING, Handbuch (n. 19), II.2, Munchen 1976, 282-309 (trad. port., Legislação e iurisprudência em Portugal nos sécs. XVI a XVIII, Braga 1976).

(3) SchOLZ (Spanische und portugiesische Rechtsprechung des 16.-18. Jahrhunderts) em H. CoING (ed.), Handbuch (n. 19), II.2, Munchen 1976, p. 1271-1342 (trad. esp. Scholz, Colecciones de jurisprudencia y de dictámenes, em Scholz/PÉrez MARTín, Legislación y jurisprudencia (n. 7), 277-336; trad. port. Legislação e jurisprudência (n. 7)).

(4) E. Holthofer, Die Literatur zum gemeinen und partikularen Recht in Spanien und Portugal, em H. CoING (ed.), Handbuch (n. 19), II.1, esp. 153 ss, 242 ss.

(5) A. M. Hespanha, Bibliografia sumária de história do direito português, em Hespanha, História do direito, cit., 165-220; já antes, Introdução bibliográfica à história do direito português, em «Bol. Fac. Dir. Coimbra» (Coimbra) 49 (1973) 47-133 e 50 (1974) 1-106; Portugal, em J. GiLissen (ed.), «Introduction à l'histoire du droit et à l'ethnologie juridique», s.l. 1977. 
panorama desta literatura dos últimos anos inevitavelmente traz consigo não pode ocultar que todos os resultados de detalhe constituem testemunhos acerca da formação do Estado moderno e do seu monopólio da criação do direito. Eventuais marchas atrás no processo da sua formação-que acabam por vezes por se ievelar depois como de sentido positivo-e ensaios de uma descentralização táctica não mudam o pano rama geral. Ao contrário do que faz J. A. EsCuDERo, cujas monografias devem ser citadas em primeiro lugar, é, por isso, de incluir logo desde o início os novos conhecimentos sobre a fisiologia do aparelho de Estado no contexto da sociedade global. Só assim se pode explicar, por exemplo, a criação do "Consejo de Ministros» espanhol através do decreto real de 19.11.1823 que pð̃e a centralização (i.e., um governo mais eficiente) em relação com o bem estar dos súbditos, ou seja, com a esfera social de acção destes últimos. Feitas estas restriçðes, são de destacar os esforços sistemáticos de ESCUDERO no sentido de trabalhar de forma nova, do ponto de vista historiográfico, o imobilizador aparelho de Estado. Ele prosseguiu na década de setenta consequentemente os seus estudos, a partir do ponto em que os tinha deixado em 1969 com a sua obra «Secretarios de Estado y del despacho" (1474-1724). Nestes quatro volumes é tornado patente, sobretudo aos observadores estrangeiros, de que modo se construiu, entre os reis católicos e Filipe V, o diferenciado aparelho de Estado da monarquia espanhola. Fenómenos do mesmo tipo estão na base do seu estudo «Los cambios ministeriales a fines del antiguo régimen» (Sevilla 1975); também aqui ele se preocupa com a descrição externa da instituição do ministério, desta vez no tempo da reforma iluminista e das cortes de Cádiz. A sua última obra, em dois volumes, «Los orígenes del Consejo de Ministros en Espana - La Junta Suprema de Estado» (Madrid 1979), centra-se de novo no séc. XVIII, considerando a Junta como a precursora do "Consejo de Ministros» de 1823 e, nesta medida, dos actuais órgãos de topo das estruturas administrativas. Já antes se tinha dedicado ao passado mais recente, numa espécie de estudo experimental, que desembocou nestes últimos resultados. Tratava-se, então, de «La Real Junta Consultiva de Gobierno (1825)», Madrid 1973. É de louvar que a tão extensa obra de Escudera reuna uma documentação tão volumosa.

Em virtude de razões de espaço torna-se forçoso dar em nota a indicação de outros estudos sobre a história da administração. $\mathrm{O}$ inte- 
resse de LALINDE, já constatado em 1970, por estes temas produziu frutos numa série de trabalhos, dos quais se destacam os que seguem as pistas estabelecidas por Garcia de Enlenia. Fornecem informação sobre disso as actas de simpósios especializados na história da administração que, desde 1967, se têm periodicamente publicado. Merecem referência especial, em virtude das suas pretensões analíticas, dois trabalhos: J. A. Santamaria Pastor, Sobre la génesis del derecho administrativo español en el siglo XIX (1812-1845), Sevilha 1973, e a introdução, aparecida ao mesmo tempo, de MARTIN-RetorTILlo/Arguli.ol a um problema chave da sociedade espanhola moderna - a relação entre a descentralização administrativa e a organização política - entre Cádiz e a segunda república (i). Além disto, e para o período anterior, é digna de menção a obra de J. GARCIA MARIN, La burocracia castellana bajo los Austrias (Sevilla 1976), uma análise baseada na literatura castelhana dos sécs. XVI e XVII, que conscientemente se compreende como um estudo prévio para uma investigação mais vasta, na qual o aspecto funcional será referido ao contexto sócio-político global.

\section{Ius commune}

Enquanto que, em Garcia Marin, a jurisdição real está no centro das atenções, duas contribuições de Tomás y Valiente e de Hespanha são dedicadas sobretudo à prática judicial. Para qualquer deles, o domínio de investigação é o ius commune ao qual é, consequentemente, atribuída a maior atenção. Quiz o acaso que, através destes estudos, tenha sido a partir de Espanha e de Portugal, que um dos problemas de momento mais sentidos tenha sido tratado. Cada um dos trabalhos estabelece balizas diferentes para a investigação; enquanto que o estudo de Tomás y Valiente sobre Castillo de Bodadilla nos apresenta um autor de uma prática processual famosa no séc. XVI e, nesta medida, um representante típico do «mos italicus», Hespanha apresenta-nos o contraste do mundo do direito erudito com a justiça leiga do antigo regime, apontando, assim, para um conceito de história do direito que facilmente se perde - quando se encara

(1) Cf. S. Martin-Retortillo Baquer/E. Argullol Murgadas, Aproximación histórica al tema de la descentralización (1812-1931) (ou S. MARTIN-RETORTILLO et alii, Descentralización administrativa y organización politica, I), 
a história jurídica unicamente como história da cultura erudita (1). Não é precisa muita imaginação para adivinhar quantas perspectivas ficam assim abertas. Nestes trabalhos encontram também o seu contraponto as investigaçð̃es sobre a estratificação da sociedade nas praxes decisórias dos tribunais superiores (2). Uma análise sobretudo estática do ius commune poria, assim, entre parênteses a sua dinâmica social. A moderna sociologia do direito mostra como pode ser rica em consequências uma mudança de perspectiva deste género, ou seja, uma perspectiva que informe sobre a função social das «subtilezas» jurídicas, ao ocupar-se do direito dos não privilegiados. Refiram-se apenas a este propósito as investigaçōes mexicanas de Gesner e a interessantíssima análise de um Sousa Santos acerca das favelas do Rio de Janeiro (3).

Infelizmente questões deste tipo são ainda um tanto longínquas dos horizontes normais.

Para a Espanha, é válido aquilo que Garcia-Gallo disse em 1979 num congresso em Varenna: «Les historiens espagnols du droit n'ont

(1) F. Tomás y Valiente, Castillo de Bobadilla (c. 1547-1605) - Semblanza personal y profesional de un juez del Antiguo Régimen («AHDE 45 (1975) 159-238; A. M. Hespanha, Les magistratures populaires dans l'organisation judiciaire portugaise d'ancien Régime, em "Diritto e potere nella storia europea. Atti del quarto Congresso Internazionale della Scocietà Italiana di Storia del Diritto") (Napoli, 9-13 Aprile 1980).

(2) F. RANIERI, Rechtsgeschichte und quantitative Geschichte. Die Verwendung historisch-quantitativer Methoden bei der Auswertung der Notariatspraxis in der neueren Privatrechtsgeschichte, em «Tijdschrift voor Rechtsgeschiedenis, Groningen-Bruxelles-The Hague 44 (1976) 333-363; em especial, Versuch einer quantitativen Strukturanalysen der deutschen Rechtslebens in 16.-18 Jahrhundert anhand einer statistischen Untersuchung der Judikatur des Reichskammergerichts, em RANIERI (ed.), Rechtsgeschichte und quantitative Geschichte, Frankfurt/Main 1977, 1-22 (cf., na mesma colectânea, P.-C. Timbal, L'exploitation des archives du Parlement de Paris - une methode et ses résultats, 23-35); e RANIERI, Die Heranziehung von quantifizierenden Methoden in der neueren Privat rechtsgeschichte. Gegenwartige Lage und Perspektiven, em W. EHBReChт (ed.), Voraussetzungen und Methoden geschichtlicher Stadteforschung, Koln-Wien 1979, 194-216.

(3) V. GeSSENER, Recht und Konflikt-Eine soziologische Untersuchung privatrechtlicher Konflikte in Mexiko, Tubingen 1976; B. Sousa Santos, The law of the opressed - The construction and reproduction of legality in Passargada, em "Law and society review», Denver (USA) 12, 1 (1977) 5-126; $O$ discurso e o poder, Coimbra 1980. 
presque accordé aucune attention au droit commun» (1). O tratamento recente da recepção portuguesa dos direitos eruditos e da respectiva praxis é também escasso, se se descontar o estudo de BraGA DA Cruz sobre a hierarquia das fontes de direito do séc. XIII ao séc. XIX (2). Entretanto, ele deve ser completado por um estudo monográfico de J. Duarte Nogueira sobre o direito subsidiário das Ordenações Afonsinas. Sobre o mesmo tema existe ainda um curto estudo de EsPINOSA GoMes DA SiLva sobre um comentário às Ordenações Manuelinas dos fins do mesmo século (3). É significativo que Hespanha, no seu curso de 1978, se reporte fundamentalmente às investigações de Braga da Cruz do início dos anos setenta, embora este se tenha ocupado preferentemente com o direito legislado e não com o «law in action». É certo que existem contributos histórico-bibliográficos como os de Garcia-Gallo sobre o "Specullum» de Pedro Belluga ou de Barrero GaRCIA sobre os repertórios ou dicionários do fim da idade média e da idade moderna, além dos importantes dados sobre os estudantes do "Colegio de Espana» de Bolonha de Perez-Martin (4); mas todos estes resultados de pormenor ainda não foram equacionados com referência à questão central do ius commune. E esforços de sistematização superficiais, como os de CARPINTERo, no sobre seu texto Mos italicus, mos gallicus e o hnmanismo racionalista (5) - ainda porque eles deixam normalmente sem referência a península ibérica - não são

(1) A. Garcia-Gallo, Le droit local et le droit commun en Catalogne, à Valence et Majorque, em «Diritto commune e diritto locale nella storia del diritto europeo. Atti del convegno di Varenna», giugno 1979, Milano 1980.

(2) G. BRAGA DA CRUz, $O$ direito subsidiário na história do direito português (separata da «Rev. Port. Hist.», 14), Coimbra 1975 (cf. a minha recensão em «Zeit. Savigny St. f. Rechtsgesch»., Weimar), Germ. Abt. 93 (1976) 522-26.

(3) N. Espinosa Gomes DA Silva, $O$ direito subsidiário num comentário às Ordenações Manuelinas atribuido a Luís Correia, Lisboa 1973. J. A. DUARTE NogueIRA, Algumas reflexões sobre o direito subsidiário nas Ordenações Afonsinas, «Rev. dir. est. soc.» 24 (1980) 279.

(4) A. Garcia-Gallo, El derecho en el "Speculum principis» de Belluga (《AHDE» 42 (1972) 189 ss.); A. M. BARRERo GARCIA, Los repertorios y diccionarios juridicos desde la Edad Media hasta nuestros dias («AHDE» 43 (1973) 331), A. PÉrez MARTIN, Los Colegios de Doctores de Bolonia y su relación con Espana («AHDE» 48 (1978) 5 ss. - aí uma lista dos vários trabalhos de Pérez-Martin relativos a este tema, em especial a referência à sua «Proles aegidiana» em quatro vols. (Bolonia-Zaragoza 1978).

(5) «Ius commune», Frankfurt/Main 6 (1977) 108-71. 
adequados a suprir aquele défice a que, por último, se referiu nomeadamente Clavero.

Foi precisamente Clavero quem, em 1977, colocou, com a nitidez aqui desejada, a temática do ius commune, do «derecho común», no centro das investigaçð̃es histórico-jurídicas da época moderna. Isto torna-se desde logo patente pelo facto de, nos «Temas de historia del derecho» de Sevilha, todo um volume ser dedicado a este círculo problemático (1). $\mathrm{O}$ facto de, em três anos, terem aparecido duas ediçð̃es deste texto revela o interesse que já se tornara manifesto, aqui e ali, nos últimos anos. Fora de Espanha é dificilmente concebível o que cste corte significa para uma história até aqui centrada quase exclusivamente sobre o mundo hispânico e, também, que impulsos puderam ser impedidos por este isolamentos. Não que deva ser dada a palavra a uma história jurídica europeia que dilua as diferenças sócio-politicas específicas. Neste ponto, o prólogo de Clavero, «Premissas culturales y sociales del 'Ius commune' europeu», traz, com o seu carácter programático, algo de novo para a Espanha, algo que deve merecer também no estrangeiro a maior atenção. Uma curta informação sobre esta introdução, escrita num estilo extraordinariamente conciso, tem que substituir aqui a recapitulação do seu tema. Leitura que, todavia, não se dispensa, sobretudo porque Clavero optou, duma forma exemplar, por ler o discurso feudal na perspectiva da transição da sociedade feudal para a sociedade burguesa e, com isto, patentear os elementos da ordem jurídica que - sem o risco de uma revolução social - permitiam o estabelecimento de um mercado nacional e o alargamento de um poder político central.

Alguns trabalhos anteriores deste autor, que agora serão brevemente caracterizados, deixam advinhar que orientação deveriam tomar os estudos monográficos neste domínio. É de começar com o primeiro grande trabalho de Clavero, a sua monografia sobre a propriedade senhorial laica em Castela (2). Com este seu trabalho, ele teve uma sorte que os historiadores do direito quase nunca ousam esperar - os seus resultados deram origem a uma controvérsia entre os historiadores

(1) B. Clavero, Temas de historia del derecho. Derecho común, Sevilla 19778, 19798 (revista e alargada).

(2) B. Clavero, Mayorazgo. Propriedad feudal en Castilla (1369-1836), Madrid 1974; cf., sobre ela, a minha recensão em «ZSS.GA» 92 (1975) 343-50. 
do direito que se seguiram, que obrigaram porventura Tunon de Lara e Fontana a repensar os seus modelos explicativos relativos à dissolução do antigo regime (1). Os acordes ob́tidos pelas posições metodológicas de Clavero têm que ser averiguados caso por caso. Ao compreender o «mayorazgo» como «institución concreta» com as suas respectivas referências históricas e ao aproximar-se das concepçð̃es teóricas do historiador da economia W. Kula, ele consegue, pelo menos pontualmente, convencer a chamada ciência histórica global da indispensabilidade dos conhecimentos de história jurídica. A sua tese fundamental da natureza jurídica da revolução burguesa dos anos trinta do séc. XIX constitui uma contribuição para a compreensão social da época moderna e mesmo da Espanha actual. Naturalmente que, para este fim, ele não podia percorrer o de resto habitual caminho da paráfrase histórico-dogmática, ainda que de recorte erudito (de que o estudo de R. DE Albuquerque sobre o direito português das represálias dos sécs. XV e XVI oferece um exemplo) (2). De forma semelhante a Hespanha, que abordou o estudo da ciência jurídica portuguesa dos sécs. XVII a XIX do ponto de vista do seu funcionamento social (3), Clavero não toma à letra, nas suas investigações sobre o "mayorazgo», os termos em que a questão era então posta; para seguir a terminologia de $\mathbf{R}$. Barthes, ele não se deixou enganar pela ilusão do referente. Tendo anteriormente apresentado no seu artigo sobre a proibição da usura as metáforas jurídicas como fórmulas culturalmente datadas de relações de poder empiricamente pré-dadas e o contornar desta proibição através das rendas creditícias da terra (censos consignativos), ele soube utilizar como instrumento explicativo a tensão entre a desigualdade social e o equilíbrio do contrato (4). A concei-

(1) Cf., sobre a discussão, B. Clavero, Notas sobre publicaciones. Señorio $y$ hacienda a finales del antiguo regimen en Castilla, em «Moneda y credito. Revista de economia" (Madrid) 135 (1975) 111-28; em especial, B. Clavero, Para un concepto de revolución burguesa, em "Sistema. Revista de ciencias sociales» (Madrid) 13 (1976) 35-54, e Clavero, Politica de un problema. La revolución burguesa, em B. Clavero, P. Ruiz Torres, F. J. Hernández Montalbán, Estudios sobre la revolución burguesa en Espana, Madrid 1979.

(2) R. DE Albuquerque, As represálias. Estudo de história do direito português (sécs. $X V$ e $X V I$ ), I-II, 1, Lisboa 1972.

(3) A. M. Hespanha, Prática social, ideologia e direito nos séculos XVII a XIX (Separata "Vértice» (Coimbra) 340-42), Coimbra 1972.

(4) B. Clavero, Prohibición de la usura y constitución de rentas, em «Moneda y credito" (Madrid) 143 (1977) 107-131. 
tuação das práticas jurídico-científica como práticas sociais é também ilustrada no seu recente sobre o conceito de interesse (1). A partir de um certo círculo doutrinal, o dos juristas que primeiro publicaram em língua vulgar no séc. XVI, ele tenta despistar as suas dificuldades na transposição dos tópicos do direito comum. Em vez de silenciar as ambivalências das teorias dessa época, ou seja, em vez de afirmar a sua coerência ou de as estigmatizar superiormente como erróneas, ele aproveita-se destas ambivalências como instrumentos de explicação. Uma observação exacta das relações textuais serve-lhe de ponto de partida para uma averiguação do vigor normativo e legitimador e, portanto, do sentido social do "cálculo» jurídico da sociedade 'señorial'. Com isto, no entanto, ele não sucumbe perante um perigo em que uma história do direito que se tem a si mesma como moderna, cai frequentemente: na sua obra, o contexto sócio-económico é mais do que um mero andaime das subtilezas jurídicas, aparecendo antes estas, em si mesmas, como indicadores sociais. Quanto às suas premissas metodológicas, ele acaba por as construir na sua ulterior dissertação sobre as questões do método nos fins do antigo regime (2). Aí, a preferência dos contemporâneos por uma certa impostação das questões é sintoma do intuito de subverter o ordenamento jurídico do direito comum, ainda vigente. A teoria do direito apresenta-se-lhe na sua substância sócio-política, uma vez que ele recusa os caminhos, mais cómodos mas a seu ver errados, de opções nacionalistas ou os de se confiar a um moderno reducionismo economicista simplificador.

É deste ponto de vista que são de fazer restrições à maior parte dos trabalhos monográficos recentes sobre o direito comum.

Isto vale, em primeiro lugar, para as investigações sobre a chamada segunda escolástica castelhana. Neste domínio, são de referir sobretudo os esforços de CARPINTERo (3) no sentido de salientar o seu papel

(1) B. Clavero, Interesse. Traducción e incidencia de un concepto del siglo XVI («AHDE» 49 (1979) 39-97).

(2) B. Clavero, La disputa del método en las postrimerias de una sociedad, 1789-1808 («AHDE» 48 (1978) 307-334).

(3) CARPINTERo BenITEZ, Sobre la génesis del derecho natural racionalista en los juristas de los siglos XIV-XVII, em «Anuario de filosofia del derecho» (Madrid) 18 (1975) 263-305; Mos italicus, mos gallicus y el humanismo racionalista. Una 
de intermediária entre o jusnaturalismo medieval e moderno. No entanto - e sobretudo no seu estudo sobre Vázquez de Menchaca torna-se claro como a preocupação do autor de procurar a originalidade sobreleva a de ligar Vázquez de Menchaca à restante realidade do seu tempo. Por razós de espaço, tem aqui que se renunciar a repetir a crítica, já feita noutro lado a Carpintero, acerca da consideração autonomística, por ele feita, da "especulación jurídica». Muito merecedor de leitura parece, em contrapartida, o que LALINDE escreveu, já em 1972/3, sobre a euforia quanto dos jusnaturalistas peninsulares; e de ponderar a forma como de suspeitou de ideológicos os pontos de vista histórico-culturais sobre eles. Uma vez que a historiografia alemã tomou parte nesta empresa, as observações de Lalinde devem ser particularmente lembradas neste local (1).

No que respeita ao direito comercial é de mencionar - além de uma nova edição revista da obra de LOBER, Spanisches Gesellschafts recht des 16. Jahrhundert (2) - a actividade do grupo de trabalho de Sevilha em volta de MARTINEZ GiJón. Assim, a contribuição de GaRCIA UleCIA sobre a forma híbrida do "contractus trinus» que libertou, pelo menos em parte, a prática comercial do séc. XVI do incómodo da proibição da usura (3). Ao lado desta, duas monografias sobre o direito das sociedades comerciais: J. M. Martinez Gió́n, La compañia mercantil en Castilla hasta las Ordenanzas del consulado de Bilbao (Sevilla 1979) e, como complemento, C. PetrT, Compañias mercantiles en Bilbao (1737-1829) (Sevilla 1980). Tal como já era prometido no sub-título de Martinez Gijón, a descrição por ele feita dos critérios segundo os quais estas sociedades são fundadas, agem, repartem os lucros e, finalmente, são liquidadas, contenta-se com a legislação e com a doutrina, embora o autor conceda, na introdução, a existência

contribución a la historia de la metodologia jurídica, em «Ius commune» 6 (1977) 108-171; Del derecho natural medieval al derecho natural moderno. Fernando Vásquez de Menchaca, Salamanca 1977 (cf., sobre esta obra, a minha recensão em «ZSS. GA» 95 (1978) 512-16).

(1) J. Lalinde Abadia, Anotaciones historicistas al jusprivatismo de la Segunda Escolástica, em «La Seconda escolastica nella formazione del diritto privato moderno. Incontro di studio», Firenze, 16-19 ottobre 1972, Milano 1973, p. 303-375.

(2) B. LOBER, El derecho de sociedades en la escolastica espanola. Trad. y revisión por A. Perez Martin, Granada 1979.

(3) A. Garcia Ulecia, El contrato trino en Castilla bajo el derecho común («HID» 6 (1979) 129-185. 
de uma relação entre a economia e o direito. Se Petit segue esta decisão metodológica sob o pretexto de que as fontes não lhe permitem outra coisa (p. 6), no melhor dos casos ele apresenta uma dificuldade específica, mas isto não basta para legitimar tal processo. Nesta perspectiva, trata-se mais de trabalhos prévios, embora importantes, a partir dos quais se poderá fazer mais tarde uma verdadeira análise histórica do campo económico graças à inclusão nesta análise das suas astruturas jurídicas.

Só quem tiver realizado a referida análise terá escrito um capítulo de um estudo sobre a progressiva juridificação de um mercado em contínuo alargamento.

No que respeita à jurisprudência, a sua apreciação está por fazer. Contudo, dispõe-se agora em geral dos nomes dos juristas mais importantes que elaboraram cientificamente a praxe decisória sobretudo de Aragão, da Catalunha e de Valência. Para isto podem ter contribuido os trabalhos prévios do autor, por ele apresentados - para Espanha e Portugal - em diversas ocasiões (1). Temos hoje informações sobre o número e localização das coleç̧̃̃es de jurisprudência, sobre o seu carácter privado ou oficial; conhecemos o modo de trabalhar dos "arrêtistes» portugueses e espanhóis, sabemos também dar-lhes o seu lugar no contexto internacional; o que até hoje continua a faltar é, por exemplo, uma análise massiva ou quantitativa das próprias decisões judiciais. Os estudos complementares do autor sobre a eficácia dos precedentes e sobre o dever de motivação do juiz podem ter aplanado o caminho para uma investigação mais intensa do mundo judiciário. $\mathrm{Na}$ massa dos materiais da tradição chegados até nós, certas dificuldades de ordem técnica podem intimidar o investigador. Modelos estrangeiros, sobretudo em França e na Alemanha, animam, no entanto, a encarar pelo menos estudos-piloto. Pois seria errado

(1) Cf. J.-M. ScHOLz, Spanische Rechtsprechungsund Konsiliensammlungen des ancien régime em «Ius commune» 3 (1970) 98-119 (trad. esp. Coleciones espanolas de jurisprudencia y dictámenes en el antiguo régimen, em «Temis. Revista de la Facultad de Derecho de la Universidad de Zaragoza» (Zaragoza) 29-32 (1971-2) 211-229; Literaturgeschichtliche und vergleichende Anmerkungen zur portugiesischen Rechtsprechung im Ancien Régime em «Rev. port. hist.» (Coimbra) 1973, 95-159; Motiva sunt pars sententiae. Urteilsbegründung in Aragón (16.-18. Jahrhundert), em «Atti dei terzo Congresso Internazionale della Società Italiana di Storia del Diritto», II, Firenze 1977, 581-98. 
identificar a jurisprudência trabalhada pelo direito comum e, portanto, apenas a que foi parcialmente tida em vista até agora, com toda a jurisprudência de qualquer dos países no período do ancien régime.

Por fim, completaremos as indicações até aqui dadas sobre as investigações acerca do direito comum com algumas notas sobre as investigações acerca da universidade. Obras de carácter geral, como a bibliografia das universidades prosseguida até à época mais recente por AJo GonZÁLEZ, não serão consideradas senão marginalmente (1). Aqui, interessa-nos sobretudo o ensino do direito. Ele constitui uma das condições essenciais de socialização do corpo de juristas, como portadores daquela cultura jurídica latinizada que traduz em conceitos as relações sociais e que é conhecida pelo conceito de direito erudito.

Em todo o caso, antes de se passar à descrição das investigações espanholas e portuguesas sobre o assunto, refiram-se os passos do manual de CorNG, onde - ainda que sumáriamente - se consideram também as faculdades jurídicas da península (2). Em Coing encontram-se uma série de referências internacionais que, no estudo de fontes locais, são correntemente omitidas.

Esta censura não pode ser feita nem a Hespanha, nem a Peset, cujos nomes são de referir em primeiro plano quando se tratar de investigaçð̌es actuais sobre a formação jurídica da época moderna nestes dois países. Tal como foi há pouco tempo resumido por PESET, por ocasião da apresentação dos seus resultados a um auditório alemão, nos últimos anos ele esforçou-se em desvendar o papel das universidades espanholas como intermediárias, nas particulares condições políticas, económicas e sociais, para a Espanha da ciência (jurídica) europeia e, nesta medida, como portadoras e divulgadoras de uma ideologia determinada (3). Os irmãos PesÉT apresentaram em 1974 os resultados de uma pesquisa que durou anos. A sua síntese ocupa-se, predominantemente, com a situação, no plano das leis e no plano

(1) C. M. Ajo González de Rapariegos y SAinz De Uniga, Historia de la Universidad hispánica, Madrid 1957 ss. (bis Bd. X, 1977).

(2) H. CoING, Die juristischen Fakultat und ihr Lehrprogramm, em H. CoING (ed.), Handbuch (n. 19), II.1, Munchen 1977, 3 ss. (55-56); as exposições correspondentes ao ensino jurídico iluminista, vol. II, 3, apareceram depois.

(3) M. PESET, Spanische Universitat und Rechtswissenschaft zwischen aufgek lartem Absolutismus und liberaler Revolution (Ius commune» 6 (1977) 172-201). 
dos factos, nas 'Facultades de leyes' e 'de canones'. Ela aborda além disso, embora resumidamente, a reforma dos planos e dos exames sob o impacto do iluminismo e da revolução liberal (1). Seria de desejar que um dia esta investigação proseguisse para a segunda metade do séc. XIX ou mesmo até à actualidade.

Sobre este ponto não devem ainda ser esquecidos as numerosas edições e os estudos monográficos sobre a mesma temática editados pelo grupo de historiadores de Valência dirigido por Mestre e pelos irmãos Peset. Refiro-me, por um lado, à publicação de documentos muitíssimo interessantes da universidade de Valência dos princípios do séc. XVIII (2). Por outro lado e sobretudo, à publicação do projecto de Mayans, digno de atenção e até hoje geralmente desconhecido pelos investigadores estrangeiros ( ${ }^{3}$ ). Ele deve o seu impulso decisivo a

(1) M. e J. L. Peset, La universidad espanola (siglos XVIII e XIX). Despotismo ilustrado y revolución liberal, Madrid 1974. Dos estudos anteriores são de destacar: M. PESET, Inéditos de Gregorio Mayans y Siscar (1699-1781) sobre el aprendizaje del derecho ("An. del semin. metropolitano de Valencia» (Valencia) VI. 11 (1966) 49-110); Correspondencia de Gregorio Mayans y Siscar con Ignácio Jordán Asso del Rio y Miguel de Manuel Rodriguez (1771-1780), em "ADHE» 36 (1966) 547-74; La recepción de las órdenes del Marqués de Caballero de 1802 en la Universidad de Valencia. Excesso de abogados y reforma en los estudios de leyes («Saitabi» (Valencia) 19 (1969) 119-148); M. e J.-L. PeSET, De la Universidad moderna a la contemporanea en Espana e El sistema de ensenanza de la Universidad de Valencia y el plan Basco de 22 de diciembre de 1766, em «Actas de 1 III Congreso de historia de la medicina», III, Valencia 1969, p. 263 ss. e 295 ss.; M. Peset, La formación de los juristas y su acceso al foro en el tránsito de los siglos XVIII y XIX («Revista gen. de leg. y jur.» (Madrid) 62 (1971) 605-672.

(2) Bulas, constituciones y documentos de la Universidad de Valencia (1707-1724). La Nueva Planta y la devolución del patronato (edición y estudio preliminar de M. Peset, M. F. Mancebo, J. L. Peset, A. M. Aguado), Valencia 1977; Bulas, constituciones y documentos de la Universidad de Valencia (1725-1735). Conflictos con los jesuitas y las nuevas constituciones (edición y estudio preliminar de M. PESET, M. F. Mancebo, J. L. Peset), Valencia 1978.

(3) A. MeSTRE, Ilustración y reforma de la Iglesia. Pensamiento politico-religioso de Don Gregorio Mayans y Siscar (1699-1781), Valencia 1968; MESTRE, Historia, fueros y actitudes políticas. Mayans y la historiografia del XVIII, Valencia 1970; Gregorio Mayans y Siscar. Epistolario, I: Mayans y los médicos (transcripción, notas y estudio preliminar de V. PESET), Valencia 1972, II. Hayans y Barriel (Transcripción, notas y estudio preliminar de A. MESTRE), Valencia 1972; III. Mayans y Marti (transcripción, notas y estudio preliminar de A. Mestre); IV. Mayans y Nebot (1735-42). Un jurista teórico y un prático (transcripción, notas y estudio preliminar de M. Peset), Valencia 1975; V. PeSeT, Gregori Mayans i la cultura de 
Mestre. O tratamento do espólio (incomparavelmente conservado) de Gregorio Mayans y Siscar (1699-1781), um dos mais famosos juristas da sua época, deu até hoje dos resultados mais dignos de nota que a historiografia hispânica produziu ultimamente no nosso domínio. Em primeira linha, a troca de cartas entre Mayans e o advogado Nebot, editada e prefaciada, de forma competente, por Peset - uma fonte simplesmente inesgotável para quem se dedique à justisprudência e à praxe desta época. Também a correspondência internacional de Mayans, para a qual remetem todos os especialistas, bem como o seu extraordinário interesse numa reforma da universidade e da organização política espanholas devem justamente atrair a atenção dos especialistas estrangeiros para um projecto de trabalho cujo esgotamento não está ainda felizmente à vista. Com isto se fez também indirectamente a introdução à análise de HeSPANHA que teve o mérito de esclarecer a reforma universitária de Pombal, realizada na mesma época, -- ao submeter a uma análise linguística formal os estatutos de 1772 e ao invocar como meta uma sua análise discursiva no sentido de Foucault (1).

\section{Direitos particulares}

Em Espanha, Clavero acompanhou o trabalho acerca das mais recentes investigações sobre o direito comum de um outro sobre os direitos particulares dos reinos da coroa espanhola. No caso de Portugal, seria correspondentemente de indicar, junto ao referido estudo de Braga da Cruz sobre o direito subsidiário português, os trabalhos de N. Espinosa Gomes DA SILVA sobre as «Ordenaçס̃es Manuelinas»

la Il-Lustració, Valencia 1975; J.C. StrodtmanN, Gregorii Maiansii, generosi Valentini, vita (Wolfenbuttelae MCCVI (texto latino-castelhano) (Presentación ce SALvador Cardona. Estudos prelimnar y traducción de A. Mestre), Valencia 1974; M. e J. L. PESET, Gregorio Mayans y la reforma universitaria. Idea del nuevo método que se puede praticar en la ensnanza de las universidades de Espanha, 1 de abril de 1767, Valencia 1975.

(1) A. M. Hespanha, Recomeçar a Reforma Pombalina? Da reforma dos estudos jurídicos de 1772 ao ensino do direito de 1972 («Rev. dir. est. soc.» (Coimbra) 19, 1 -4 (1972) 5-34; Forma e valores nos Estatutos Pombalinos da Universidade (1772), em Hespanha, $A$ história do direito na história social, Lisboa 1978, 150.64. 
do início do séc. XVI e as «Ordenações Filipinas» do começo do séc. XVII, ou seja, sobre as duas compilações portuguesas de direito pátrio (1).

No caso dos direitos particulares de Castela, Clavero insiste em que, nesta expressão, são de compreender vários núcleos regionais de integração, diferentes uns dos outros; nomeadamente as juı isdições senhorial, eclesiástica, urbanas ou corporativa. Cada uma destas massas jurídicas divergentes teriam constituido ordenamentos prévios em relação ao direito comum (2). Que opç̃es históricas comprometerão uma compreensão prevalentemente "federativa» do chamado direito foral é algo que se tornará evidente quando, a final, ele tomar partido acerca da actual discussão sobre dos direitos históricos, por exemplo de uma Catalunha autónoma ou das províncias bascas independentes. $\mathrm{Na}$ Espanha a investigação histórica sobre o direito foral cruza-se, com rara evidência, com a actualidade política. Assim, empreendimentos editoriais como o de Perez MarTín sobre os foros de Aragão (3) encontram-se em plena actualidade política - independentemente de se saber se tais publicações são, nos casos concretos, motivadas por ela.

Uma vez que foi recentemente aprontado por Perez Martin um panorama da última bibliografia, bem como das publicações de fontes, do direito especial de Castela, Países Bascos, Navarra, Aragão, Catalunha e Baleares, dispensamo-nos de semelhante apresentação. Em vez dela, salientem-se alguns recentes trabalhos especialmente instrutivos, constituindo-se assim um suplemento à obra antes citada. Desde logo, a dissertação de EGEA I FERNANDEZ/GAY I ESCODA

(1) N. J. E. GomeS DA Silva, Algumas notas sobre a edição das Ordenações de António Leitão Homem (separata da «Rev. dir. est. soc.» 24 (1-3 (1977)), Coimbra 1977.

(2) B. Clavero, Notas sobre el derecho territorial castellano, 1367-1445 («HID» 3 (1976) 141-165); Temas de história del derecho. Derecho de los reinos, Sevilla 1977, em especial 7-14; cf. também C. PETIT, Derecho común, derecho castellano. Notas de literatura juridica para su estudio siglos XV-XVIII) em "Tijdschrift voor Rechtsgeschiedenis» (em impressão).

(3) Fori aragonum vom Codex de Huesca (1247) bis zur Reform Philipps II (1547) nach der Ausgabe Zaragoza 1476/7, mit den handschriftlichen Glossen des Martin de Pertusa und mit Erganzungen nach der Ausgabe Zaragoza 1542, 1548 und 1576. Edição fac-similado com uma introdução de A. Perez Martín, Vaduz (Liechtenstein) 1979; Las glosas de Martín de Pertusa a los fueros y Observancias de Aragón. Transcripción y edición por A. Perez MARTín (em preparação). 
sobre a eficiência normativa do direito catalão até à Nueva Planta (1714) (1).

No entanto, na primeira fila conta-se indubitavelmente a já indirectamente citada introdução de Clavero, Derecho de los Reinos (Sevilla 1977). Ao lado desta deve colocar-se o trabalho de LALINDE, aparecido em 1977 em Zaragoza, Los Fueros de Arágon - uma síntese que abrange o período desde a idade média até à actualidade, em que o autor, ao contrário do que é habitual, não se limita às informações de interesse localizado, mas soma a estas uma informação densa de carácter geral, elaborada com grande rigor. Neste sentido, aconselha-se por exemplo a leitura do quinto capítulo que se ocupa dos enxertos dos Estados absoluto e liberal no conjunto remanescente das normas de direito aragonês. Clavero esclarece este tema nas conclusð̃es do seu livro «Derecho de los reinos». A este propósito, ele recorda a perspectiva castelhanizante da «Novissima recopilación» de 1805 como última compilação espanhola ao estilo antigo; a subsequente unificação jurídica sob o signo da constituição e da codificação; e a historiografia dos direitos forais, ainda hoje raramente ultrapassada, mas frequentemente manipulada para negar ou incensar estes direitos.

Não é aqui o lugar de entrar em pormenores sobre o actual debate espanhol acerca dos direitos forais. Sobre isto, o autor prepara um ponto da situação, a publicar em «Ius commune». Apenas porque se trata de um tema de história jurídica - ou melhor talvez, apenas porque a historiografia dos direitos forais ganhou, graças à Constituição de 1978, um valor instrumental de primeira ordem - esboçamos aqui esta problemática. Como introdução, basta uma das muitas declarações publicadas pelos chamados "foralistas», a do presidente do Supremo Tribunal das Baleares, que liga as novas garantias constitucionais a uma dinamização ou mesmo um renascimento do seu direito especial, formado ao longo da história (2). Mais profundos, talvez, por um lado ROCA I TRIAS e, por outro lado, o ponderado "plaidoyer» de LASARTE que, ao fim e ao cabo, aponta para a uniformidade do

(1) J. Egea i Fernandez/J. M. Gay I Escoda, Eficácia de las normas de la tradició juridica catalana des de la Baixa Edat Mitjana fins al decret de Nova Planta («Rev. jur. de Cataluna/Barcelona) 78 (1979) 249-94 e 505-86.

(2) Cf. C. Rodriguez-Aguilera, El futuro de los derechos forales o especiales em «Rev. jur. de Cataluna» 78 (1979) 231-6. 
direito privado (1). Sem querer com isto exprimir um juízo definitivo, parece-nos na verdade, neste momento, ser sobretudo oportuno o aviso de Clavero que, a partir do contrasenso histórico de uma garantia constitucional dos chamados direitos históricos e, assim, do abandono do carácter soberano da criação do direito, recomenda uma indispensável análise crítica da questão, no sentido dessa ciência jurídica historicamente orientada pela qual ele fundamentalmente combate (2). Para isto seria de atender - o que em Espanha é obscurecido pela falta de distanciamento em relação ao objecto - à perspectiva mais elevada do controle do discurso. Pois não é de excluir que tudo isto não seja senão uma variação actual das estratégias de partilha do poder, embora a finalidade última continue a ser a estabilidade social. O carácter equívco das actuais discussões acerca da «descodificação» na civilística alemã e da «re-territorialização» do poder em Espanha significam que apenas uma disciplina de segunda ordem (uma meta teoria) pode explicar o actual arranjo do discurso jurídico. É no entanto digno de nota que, em Espanha, a história e a ciência do direito estejam a desempenhar aqui um papel decisivo.

\section{Estado de direito burguês}

A actual confrontação em torno dos direitos particulares autónomos de natureza regional dá a deixa para a passagem para a consideração do estado actual da investigação sobre o passado recente.

Antes de todas, as obras sobre a polémica em torno de um código civil para toda a Espanha e, assim, em torno duma questão nuclear do sistema jurídico burguês; polémica que, com o constitucionalismo e a instauração, no plano do direito material, de uma ordem jurídica da propriedade visando o mercado, traçou a transição para o Estado

(1) Cf., v.g., E. Roca I TRIAS, El derecho civil catalán en la Constitución de 1978, em «Rev. jur. de Catalnha» 78 (1979) 7 ss.; C. LASARTE, Autonomias y derecho privado en la Constitución española, Madrid 1980. Cf., ainda, F. Tomás Y VALIENTE, Los «derechos historicos» de Euskadi, em «Sistema» 31 (1979) 9 ss. (um pouco modificado no seu «Manual p. 472 ss).

(2) B. Clavero, Historia juridica y codigo politico. Los derechos forales y la constitución («AHDE» 50 (1980)). 
de direito liberal sob o império das relaçðes de produção capitalistas (1). Uma interpretação deste tipo da história do direito espanhol do séc. XIX conduz directamente às dificuldades com que se viu confrontada a história jurídica espanhola que se ocupou dos últimos dois séculos. E o que a seguir se dirá, vale ainda mais fortemente para Portugal. Neste domínio, as tarefas criadas por um desleixo de muitos anos são imensas; tão imensas que questões situadas em pontos-chave, como a controvérsia acerca de um direito privado uniforme ou tendencialmente federativo, não podem ainda hoje ser esclarecidas em toda a sua dimensão. Neste ponto, tal a contínua separação entre as esferas privatísticas e político-publicistica contribui para manter a situação. $\mathrm{Na}$ base de tudo, está a falta de conceptualizaçð̃es teóricas que interpretem o discurso desta época. Antes que de parafrasear este discurso trata-se de o decifrar ou descodificar. Com isto, não se faça a injustiça de desconhecer a mudança verificada neste domínio nos anos setenta. Trata-se antes de incitar as pessoas a não se satisfazerem com o que se obteve. $\mathrm{Na}$ verdade, os progressos obtidos tornam-se imediatamente visíveis para quem leia as comunicações de D'Ors e de Gibert (2) ao congresso de história do direito de Florença de 1973 ao lado dos estudos, de que se falará ainda mais em pormenor, de Peset, Clavero, Tomás y Valiente, Roca i Trias, Lasarte e, agora e sobretudo, de Salvador y Coderch. À sua disponibilidade para a colaboração, ao seu estímulo e à sua capacidade de desafio, deve o autor ter podido dar notícia desta última evolução (3).

Se se abstrair de uma síntese como a de Alejandro Garcia e GaCto Fernández (4), o esclarecimento da história da codificação tem sido feito através de contribuições pontuais. Como prova, refiram-se os trabalhos de edição de CASABó sobre a codificação do direito penal da terceira década do séc. XIX e o estudo de Tomás Y VALIENTE,

(1) Neste sentido, F. Tomás y VALIENTE, Manual de historia del derecho espanol, Madrid 1979, 401 ss.

(2) R. GIBERT, La codificación civil en España (1752-1889), em «La formazione storica del diritto moderno in Europa", II, Firenze 1977, 907-935; A. d'Ors, Los derechos civiles regionales de la España moderna, ibidem 935-41.

(3) Cf., em especial, J.-M. Scholz (Spanische und portugiesische..., n. 22); estão em preparação os capítulos relativos à ciência jurídica dos dois países; de seguida, serão referidos outros estudos.

(4) J. A. Alejandre Garcia/E. Gacto Fernandez, Temas de historia del derecho. Derecho del constitucionalismo y la codificación, I-II, Sevilla 1978-9. 
Los derechos históricos de Euskadi, que - apesar de relativo apenas aos países bascos - é o único que se encontra no seu «Manual» para a problemática da unificação do direito (1). Por outro lado, cumpre informar acerca das novas investigações sobre o projecto de um Código Civil de 1851, pois com elas SALvador y CoDERCH conseguiu pôr em questão uma série de lugares comuns. Como era de esperar, este trabalho segue $o$ conflito, em torno deste plano fracassado, entre $o$ unitarismo castelhano e o particularismo foraleiro; surpreende as instituições catalãs concretas e as suas implicaçð̃es sociais e económicas; e consegue finalmente abalar, só em $1980 \ldots$, a lenda de uma posição afrancesada orientada para um centralismo unilateral que seria de uma meia dúzia de juristas comprometidos no projecto (2). Estes trabalhos de sondagem, que LASSO GAITE e o autor podem ter incentivado com os seus trabalhos prévios de natureza arquivística e bibliográfica (cf. supra), devem um dia permitir uma síntese, que atribua às inovaçð̃es jurídicas o seu lugar central na construção teórica da moderna sociedade burguesa.

Quem quiser dar informaçð̃es sobre os trabalhos mais recentes de história constitucional encontra informes correspondentes nos trabalhos preparatórios das constituições portuguesa de 1975 e espanhola de 1978; provocados pelas sucessivas edições de normas constitucionais e de outros textos oitocentistas e novecentistas directamente relacionados com elas, surgem vários trabalhos que citam também a última literatura aparecida (3). Perante estes textos - que se limitam em geral a uma paráfrase das constituições -, não pode conter a impressão de que a sua predominante atenção para questões relativas a aspectos textuais

(1) J. R. Casabó, El proyecto de Código Criminal de 1831 de Sainz de Andino. Estudio prelimnar y edición, Murcia 1978, El proyecto de Código criminal de 1834. Estudio preliminar y edición, Murcia 1978.

(2) P. SAlvador y CODERCh, El proyecto de Código de derecho civil de 185I $y$ el derecho civil catalán («Rev. jur. de Cataluna» 79 (1980) 49-98, 313-72).

(3) Cf., v.g., M. Artola (ed.), Partidos y programas políticos, I-II, 1974-5; E. Tierno Galván, (ed.), Leyes politicas españolas fundamentales (1808-1936), Madrid 19758; J. Tomás Villa Roya, Breve historia del constitucionalismo español, Barcelona 1978; J. Solé TURA/E. AJA, Constituciones y periodos constituyentes en España (1808-1936), Madrid 19778, 19788; F. TomÁs y VALIENTE, Manual (n. 63), Madrid 1979, 436-464; para Portugal, J. Miranda, As constituições portuguesas de 1822, 1826, 1911, 1933 e 1976, Lisboa 1976; e J. Gomes Canotilho, Direito constitucional, Coimbra 1979 (Introdução) 7. 
deixa em aberto problemas que são tanto mais urgentes quanto se colocam em publicaçð̃es da mesma época, sobre as cortes aragonesas e castelhanas (1), relativos à dissolução do antigo regime. Especialmente prometedor é o artigo com o título «Notas para una nueva historia del constitucionalismo espanol» publicado por TOMÁS Y VALIENTE em Abril de 1977 na revista de ciências sociais «Sistema».

A situação da investigação sobre a história da preparação do Código Civil português de 1867 domina-se com facilidade. Aqui, em gera apenas, repetem-se os dados mais elementares. O mesmo valha para outros domínios da codificação. Uma excepção é representada pela interpretação filosófica da codificação portuguesa de direito privado feita por F. J. Veloso (2). De resto, não existem sequer, na maior parte dos casos, panoramas bibliográficos, apesar do contributo de BRAGA DA CRUZ (3). É precisamente sintomático que só o Autor tenha encontrado os fundos arquivísticos de um projecto iluminista do "Novo Código» (1778) no Arquivo Nacional da Torre do Tombo, cuja edição está em preparação. Para além disso, o Autor esforçou-se por dar uma interpretação da literatura da época, que apresentou como significativa de uma estratégia burguesa da teoria da propriedade e que, portanto, havia de se consumar nas concepções do ulterior Código Civil (4). A sua contribuição para o «Manual» de CoING (cf. supra) constituirá o primeiro panorama da legislação portuguesa (e sobretudo da história da codificação) do último século.

Mais difícil, em contrapartida, é avaliar a situação para o caso de Espanha. Para além do mais, importa salientar que, hoje, sobretudo os historiadores mais modernos, estão conscientes da intervenção fundamentalmente inovadora do chamado movimento da codificação, entre o iluminismo e o Código Civil de 1888/9. O facto de, em virtude da estrutura particular do direito espanhol, o processo de codificação

(1) Cf., v.g., J.-M. Pérez-Prendes, Cortes de Castilla, Granada 1974; L. GoNzález ANtón, Las Cortes de Aragón, Zaragoza 1978.

(2) F. J. Velozo, Na iminência de um novo Código Civil Português. Orientação filosófica do Código de 1867 e do actual projecto ("Brotéria» (Lisboa) 83 (1966) 145-174).

(3) G. Braga da CRuz, (ed.), Código civil português. Exposição documental, Lisboa 1966, 13-52.

(4) J.-M. Scholz, Eigentumstheorie als Strategie portugisesischen Bourgeoisie von 1850, em "Quaderni fiorentini per la storia del pensiero giuridico mo2trno» (Firenze) 5-6 (1976/7-1978) 339-461 (está em preparação uma versão portuguesa). 
não estar encerrado, estimula ainda mais o trabalho de investigação. No entanto, e como já foi referido, este interesse é de fresca data. Até há pouco era sensato terminar as exposições de história contemporânea no patamar da segunda metade do séc. XIX. Também aqui um exemplo pode ajudar a comprovar o qurse afirma. Refiro-me ao projecto, publicado há poucos meses, do Código Civil de 1836.

É característico que mesmo o Manual extraordinariamente informado de TOMÁs Y VALIENTE não dedique a este projecto senão algumas linhas, servindo de testemunho o próprio título do capítulo - «La oscura etapa anterior a 1851». Isto é tanto mais estranho quanto Tomás y Valiente - nisto seguindo Clavero - situa nos anos compreendidos entre $1 \leqslant 36$ e 1843 o período decisivo da revolução burguesa, i.e., da formulação jurídica da nova ordem social (1). Lasarte prova de que modo se está cada vez mais consciente desta lacuna. No seu livro, muitissimo importante, dedicado sobretudo à codificação do direito privado e comercial, aparecido em Janeiro de 1980, ele deplora não ter podido ler $o$ já citado manuscrito de Salvador y Coderch sobre o projecto de codificação de 1851 , então em curso de impressão, pois por aí se aborda o projecto de $1836{ }^{(2)}$. E, na verdade, Salvador y Coderch ocupa-se com este importante projecto por o ter podido estudar no Arquivo da Comissão Geral da Codificação (Ministério da Justiça, Madrid) (3). Um pormenor destes não teria constituido mais do que um acaso feliz se poucos anos antes RocA I TRIAS não tivesse podido remeter pela primeira vez, com orgulho infelizmente justificado, para os arquivos parlamentares respectivos (4). Face à inactividade de muitos anos esta démarche analítica, que nos poderia parecer evidente, não o é de todo em todo.

De encarecer é o trabalho de todos aqueles que, apesar do desinteresse geral, tentam compensar o atrazo da história da codificação. Ainda que isto não seja habitual, comecemos pela crónica da codificação de LASSo GaITE uma vez que é a ele que se deve a organização dos arquivos da referida comissão da codificação e, com isto, dos mais

(1) Cf. Tomás y Valiente, Manual (n. 63), 404-6; 574-5; Clavero, Politica de un problema. La revolución burguesa (n. 38).

(2) LASARTE, Autonomias y derecho privado (n. 61), 69.

(3) Salvador, Proyecto... de 1851 (n. 68), maxime 55 ss., 80 ss., 90 ss.

(4) E. Roca I TRIAS, La codificación y el derecho foral (Rev. de der. priv.», Madrid 1978) 596-642 (597). 
importantes elementos de trabalho( ${ }^{1}$ ). Quase ao mesmo tempo e acentuando uma interpretação de tipo sociológico, PESET ocupou-se dos primórdios da época da codificação. Tal como hoje SALVADOR y CoDerch o fez com o projecto de Garcia Goyenas de 1851, Peset explorou pela primeira vez, em três estudos fundamentais, as tentativas de codificação de Mora y Jaraba (1748), das Cortes de Cádiz (1812) e do chamado "Trienio liberal» (1821-1823) (2). Com os seus enormes conhecimentos sobre a Espanha iluminista, demonstrados sobretudo nos seus trabalhos sobre Mayans e sobre a relação entre o direito romano-canónico e o "direito pátrio» (3), bem como nas suas inúmeras publicaçס̃es sobre a universidade absolutista e liberal, ele pôde suprir as mais importantes lacunas de conhecimentos. A ele se sentem ainda hoje obrigados todos os que, como Gacto, Lasso, Tomás y Valiente, Lasarte e o Autor $\left({ }^{4}\right)$, tentaram dar um panorama geral desta matéria. $\mathrm{Na}$ mesma medida, isto é também válido para outros modelos explicativos.

Também quanto a estes Clavero deve ser referido (5). No seu trabalho "La idea de Código en la Ilustracion Juridica», aparecido em 1979, ele acentua os aspectos normativos e metodológicos da codificação para, por sua vez, a distinguir da ideia de «ordem jurídica» do direito comum. Ao propor-se analisar as relações de coexistência e de sequência das proposições jurídicas da época, Clavero concebia ao mesmo tempo a Recopilación de 1805 como um modelo de sinal contrário, dominado pela doutrina. É a partir daqui que, para ele, as normas codificadoras se libertam, dum lado, da ciência jurídica tradicional e doutro, da história. Neste ponto coincidem de novo as suas concepçð̃es acerca dos manuais de instituiçð̃es da segunda metade

(1) Cf. para os vários volumes, a «Crónica», p. 10, n. 1.

(2) M. PeSET, La primera codificación liberal en Espana (1808-1823), em «Rev. crit. de der. inmob.» (Madrid) 48 (1972) 125-57; Una propuesta de código hispano-romano, inspirada en Ludovico Antonio Muratori, em «Estudios juridicos en homenaje al Professor Santa Cruz Teijeiro", Valencia 1974, 217-260; Análisis y concordancias del proyecto de Código Civil de 1821 («An de der. civ.» (Madrid) 1975, 29-100).

(3) M. PESET, Derecho Romano y derecho real en las Universidades del siglo XVIII («AHDE» 45 (1975) 273-339).

(4) Cf. J.-M. Scholz (Spanische, supra, p. 10, n. 1), em H. CoING, Handbuch, III, 1-2, Munchen 1981.

(5) «HID» 6 (1979). 
do séc. XVIII espanhol (1) com as ideias expostas num ensaio de análise discursiva do Autor. No ensaio intitulado Penser les institutes hispano-romaines o Autor ocupa-se em primeiro linha com a aplicação das propostas semiológicas, numa linha intermédia de Foucault e Kristeva, procurando testar nos referidos textos a deslocação das estruturas de poder (2). Ainda aqui, a problemática tradicional da confrontação semântica dos direitos nacional e comum é afastada e, em vez dela, surge em primeiro plano uma reorganização textual que favoreça um legislador estadual todo poderoso; da mesma maneira, no meu anterior trabalho Unidad y diversidad en la codificacion, cheguei à conclusão de que o discurso da codificação do séc. XVIII não devia ser aceite como tal. O que importará é antes mostrar como as opçð̃es contemporâneas - baseadas na utilização dos mesmos instrumentos pró ou contra a codificação centralista são estratégias diferentes, mas convergentes no plano (em última análise fundamental) da estruturação do poder na sociedade burguesa (3). Outras análises, já planeadas, deste tipo irão nos próximos anos favorecer a compreensão daquilo que é geralmente conhecido como o movimento da codificação e no estudo do pese, se tende, normalmente de forma demasiado apressada para o estudo dos conteúdos, esquecendo a forma.

Sobre as transformações de conteúdo da sociedade senhorial dão actualmente informações uma série de estudos, sobretudo no plano da constituição de um novo conceito de propriedade; estudos estes que, no fundamental, abrangem quatro círculos de problemas. Em primeiro lugar, apareceu o desvendamento da ıunção social desta nova ordem da propriedade. Neste plano, são de referir em primeiro lugar, as análises de Peset, Clavero e do autor que, nos «Itinerari moderni della proprietà», organizados por P. Grossi, procuraram fazeı o levantamento do mundo ibérico do séc. XIX (4). No mesmo sentido,

(1) Cf. sobre isto ainda Clavero, Disputa del método (cit.).

(2) Cf. "Quaderni fiorentini...» 8 (1980).

(3) Cf. Memorias del segundo Congresso de historia del derecho mexicano, México 1980.

(4) J.-M. Scholz, Eigentumstheorie als Strategie portugiesischen Burgertums vou 1850, em "Quaderni fiorentini...» 5-6 (1976-7/1978) 339-461; M. PESET, Derecho $y$ propriedad en la España liberal (ibid., p. 463-507), B. Clavero, "La propriedad considerada como capital». En los origenes doctrinales del derecho actual español (ibidem, 509-548); cf. ainda M. Peset, Acerca de la propriedad en el Code («Rev. crit. de der. inmob.») 52 (1976) 879-890. 
o ulterior estudo de Hespanha, $O$ jurista e o legislador na construção da propriedade burguesa-liberal em Portugal (1). Ao segundo grupo pertencem todos os contributos polémicos que se confrontam com a tese de Moxó sobre a abolição do sistema senhorial a partir das Cortes de Cádiz e que, com isto, se preocupam com a elaboração de um conceito científico de revolução burguesa. De novo, foi Clavero quem, aqui, tomou o comando (2). Um grupo de trabalho de Valência, sob a direç̧ão de PESET, está neste momento a aprofundar esta questão nos seus pontos particulares com base nos dados locais dos fins do séc. XVIII. O terceiro campo problemático acerca da terra como meio de produção economicamente mais importante centra-se sobre o problema da desvinculação na sequência das primeiras cortes liberais. Neste campo foi fundamental o estudo de ClAVERo sobre o mayorazgo castelhano que iluminou a questão do estabelecimento de um mercado fundiário exigido pelos princípios da economia clássica (3). Falta, finalmente, falar das investigações que se ocupam com a «desamortização», ou seja, com a integração dos bens de mão morta no património nacional e com a sua posterior alienação para particulares. Esta questão congrega hoje um número dificilmente abarcável de historiadores espanhóis. Do lado dos historiadores do direito, destaca-se apenas Tomás Y VALIENTE (4). Expressamen e citado - porque passado por alto com facilidade - T. Martin Y Martin, com o seu trabalho Aproximación a la desamortización en Portugal (5). O mesmo é válido para as contribuições, publicadas na revista "Análise Social» (1980) e integradas num colóquio realizado em 1979 sobre o séc. XIX português; penso, sobretudo, em L. EspinHa dA Silveira, $A$ venda dos bens nacionais (1834-43). Uma primeira abordagem; MARIA DE

(1) Cf. A. M. HeSPanha, História das instituições II, 1979-80, p. 3-120.

(2) Cf., em especial, B. Clavero, Política de un problema, cit.; P. R. Torres, Los motines de 1766 y los inicios de la crisis del Antiguo Régimen (ibid., p. 49-112); J. HeRnÁNDEZ MONTALBÁn, La cuestión de los señorios en el processo revolucionário burgués. El trienio liberal (ibid., 113-58). Sobre os estudos preparatórios de B. Clavero, v. supra, ps. $15 / 6$.

(3) Clavero, Mayorazgo (cit.).

(4) Cf., em especial, F. TOMÁs Y VALIENTE, Recientes investigaciones sobre la desamortización. Intento de sintesis, em «Moneda y credito» 131 (1974) 95-160.

(5) «Hispania. Revista espanola de historia» (Madrid) 140 (1978) 595-616. 
FÁtima Coelho, $O$ instituto vincular. Sua decadência e morte. Questões várias; MARIA DE FÁtIMA BRANDÃo e R. Rowland, História da propriedade e comunidade rural. Questões de método; MARIA DE Fátima Brandão e Ruy Graça Feijó, $O$ discurso reformador de Mousinho da Silveira. A indicação das últimas investigações sobre as mais importantes intervenções legislativas no decurso do séc. XIX português e espanhol será dada pelo autor com maior desenvolvimento no «Manual» de Coing, abrangendo a disponibilidade da propriedade fundiária, a reorganização do crédito agrário, a nova conformação do direito da família, bem como do direito sucessário (1).

Deve ser tido como facto característico a circunstância de Tomás Y VALIENTE, no seu Manual de 1979 não ter julgado a jurisprudência do séc. passado digna de relance e de ter apenas esboçado a evolução doutrinal da mesma época. Uma vez que ele, neste último ponto, se apoia apenas nos trabalhos preliminares de PESET sobre o ensino jurídico da primeira metade do séc. xIx, a razão de ser deste juízo torna-se ainda mais verosímil. No entanto, PeSET ainda em 1977 considerava francamente que uma análise formal ou de conteúdo da bibliografia por ele utilizada era insuficiente (2). Tendo em conta as obra de P. v. Oertzen, Die soziale Funktion des staatsrechtlichen Positivismus (1953; reed. Frankfurt/Main 1974), de M. FIORAVANTI, Giuristi e costituzione politica nell'ottocento tedesco (Milano 1979), ou mesmo os estudo K.-H. LADEUR (3), sempre orientados historicamente, sobre o direito constitucional e administrativo - estudos que

(1) Cf. J.-M. Scholz (Spanische und portugiesische Einzelgesetzgebung des 19. Jharhundert auf dem Gebiet des Privatrechts), em H. CorNG (ed.), Handbuch cit., III 1, Munchen 1981.

(2) M. PESET, Spanische Universitat und Rechtswissenschaft cit., p. 195. Sejam ainda referidos os três seguintes trabalhos de PESET: La ensenanza del derecho y la legislación sobre universidades durante el reinado de Fernando VII. 1808-1833 («AHDE» 38 (1968) 220-375); Universidades y ensenanza del derecho durante las regencias de Isabel II. 1833-43 («AHDE» 39 (1969) 481-544); El Plan Pidal de 1845 y la ensenanza en las Facultades de Derecho («AHDE» 40 (1970) 613-651).

(3) Cf., especialmente, K.-H. LADEUR, Rechtssubjekt und Rechtsstruktur. Versuch uber die Funktionsweise der Rechtssubjektivität, 1978; Vom gesetzesvollzug zur strategischen Rechtsfortbildung in: Leviathan. Zeitsschrift $f$. Sozialwissenschaft 7 (1979) 339-372; Strukturwandel der Staatsrechtsideologie in Deutschland des 19. Jahr., in F. HASE/K.-H. LADEUR, Verfassungsgerichsbarkeit und politisches System. Studien zum Rechtstaatsproblem in Deutschland, 1980, 15-102. 
se distinguem de outras obras alemãs sobre o mesmo tema pela profundidade da sua reflexão e que por isso constituem um caso excepcional no contexto alemão - os trabalhos decisivos quanto à Espanha e a Portugal estão ainda para aparecer. Característico do nível de investigação aí vigente é a dissertação de Gibert sobre a influência de Jhering em Espanha, tantas vezes citada neste contexto. No fundamental, tanto aqui como no trabalho de Gibert, Ciencia juridica española, trata-se de um mero enumerar de dados externos ou, na melhor das hipóteses de uma paráfrase das obras mais importantes (1). O mesmo vale para a obra de BRAGA DA CRUZ, comemorativa do centenário da mais famosa revista jurídica portuguesa, verdadeira mina de informaçðes que preenche uma lacuna (2). Já uma leitura, mesmo corrida, da exposição de pendor sobretudo jurídico-filosófico de GIL CREMADES e daqueles outros autores reunidos no volume dos "Anales de la cátedra Francisco Suarez» sobre o «Pensamiento juridico español del siglo XIX» (3) nos informa da quantidade de materiais ainda por trabalhar. E para isto não basta, como o fez VALLET DE Goytisolo por ocasião do segundo centenário do nascimento de Savigny, preparar uma síntese, rica em informações mas de tipo antológico, sobre a Escola Histórica da Catalunha (4). Esperemos que o «Festschrift» Savigny, da iniciativa dos antes citados 'Anales', liberte as energias necessárias para a elaboração científica da doutrina espanhola - e portuguesa dos últimos cento e cinquenta anos. Com as Notas sobre la introducción de la Escuela Histórica de Savigny en España, de M. FigueRAS (5), nada foi na verdade feito pois uma recolha de dados não pode substituir a sua análise. Em que medida, no entanto, o contexto

(1) R. Gibert, Jehring en España, em F. WieACKer/C. Wollschlager (eds.), Jehrings Erbe. Gottinger Symposium, Güttingen 1970, 40-67; Ciencia juridica española, Granada 1971.

(2) G. Braga dA CRUz, A Revista de legislação e jurisprudência, I., Coimbra 1975,882 pp. (!).

(3) Cf., em especial, J. J. Gil Cremades, El reformismo español. Krausismo, escuela historica, neotomismo, Barcelona 1969; citem-se, "Anales de la Cátedra Francisco Suarez) (Granada) 11,2 (1971) 9-336.

(4) J. VAllet DE Goytisolo, Cotejo con la Escuela historica de Savigny, em «Rev. jur. de Cataluna» 78 (1979) 587-641, 771-819 e 79 (1980) 7-47, 279-311, 567-69 (continuação prevista).

(5) Reimpresso em Savigny y la ciencia jurídica del siglo XIX (igual a «Anales de la Cátedra «Francisco Suarę» 18-19 (1978-9) 371-93). 
histórico aí podia ser esclarecedor demonstra-o CLAVERo na reedição de um texto de Giuseppe Salvioli (1). Em ligação com o estado das pesquisas internacionais, tal como já se apresentara no número especial 3-4 (1974/5) dos Quaderni Fiorentini, ele pôde descobrir a versão espanhola do "socialismo jurídico» como uma revisão metodológica moderada da ciência jurídica liberal então dominante. O Autor esforça-se por aplicar os resultados gerais assim estabelecidos no seu trabalho, atendendo já a eles no artigo, destinado ao «Manual» de Coing, sobre a ciência do direito privado e do direito processual privado de Portugal e de Espanha do séc. passado. No mesmo lugar se tentará preencher as lacunas que permanecem abertas na historiografia dos dois países sobre a sua jurisprudência.

Muito presumivelmente este panorama cria alguma confusão. À história do direito estabelecida de Espanha e de Portugal a sistematização aqui adoptada parecerá ter colocado as coisas de pernas para o ar. Os leitores estrangeiros que já se interessavam pela história do direito da Península Ibérica darão pela falta de nomes e de apreciações correntes, bem como dos cânones de apresentação até agora habituais. Mas teria sido completamente despido de interesse subscrever as posiçðes da hierarquia estabelecida e do seu discurso, quando uma (é certo que ainda pequena) comunidade científica se prepara para os dissolver. Nesta medida, trata-se aqui sobretudo de uma modificação de perspectiva que hoje abala já o consenso dominante até há poucos anos. Por outro lado, trata-se de evitar que informações aqui prestadas se desactualizem imediatamente.

Quem tencione atender na próxima década à história do direito de Espanha e Portugal, sobretudo para o período da época moderna, deve compreender a nova história do direito na rede das suas diferenças. Só depois de se ter rompido a estreiteza de uma história do direito que fazia hinos à sua própria autonomia serão integráveis neste sistema de comunicação as referências textuais da chamada história geral.

Estas referências materializam-se em determinadas obras-cânone, centros de investigação e séries de publicações. Independentemente das eventuais informações isoladas, estas referências abrem perspec-

(1) G. Salvioli, El derecho civil y el proletariado. Estudio preliminar y y edición de B. Clavero, Sevilla 1979. 
tivas a que uma historiografia jurídica portuguesa e espanhola não pode deixar de ser sensível. Entre elas contam-se, ao lado da monumental obra de P. VILAR, La Catalogne dans l'Espagne moderne (Paris 1962), em primeira linha G ANES, Las crisis agrarias en la España moderna (Madrid 1970), J. FontANA, La quiebra de la monarquia absoluta (Barcelona 1971), J. A. Maravall, Estado moderno y mentalidade social. Siglos XV-XVII, Madrid 1975, A. Dominguez OrTIZ, Sociedad y Estado en el siglo XVIII español (Barcelona-Caracas-México 1976), M. Artola, Antiguo Regimen y revolución liberal (ibidem 1978), A. M. BERNAL, La lucha por la tierra en la crisis del antiguo regimen (Madrid 1979) e as obras de M. TUnON De Lara. Para Portugal sejam referidas as obras de A. SiLBert, Le Portugal méditterranéen à la fin de l'ancien régime (Paris 1968), M. HALPERn Pereira, Livre câmbio e desenvolvimento - Portugal na segunda metade do séc. XIX (Lisboa 1971), V. MaGAlhães Godinho, Estrutura da antigo sociedade portuguesa (Lisboa $1971^{1}$ e 19773 ) e M. Villaverde CABRAL, O desenvolvimento do capitalismo em Portugal no século XIX (Porto 1976).

Como centros institucionais merecedores de toda a atenção, são dignos de referência, por exemplo, os "Colóquios de Pau» e as iniciativas da Casa de Velasquez. Como terá resultado suficientemente claro, a leitura dos "Annales de historia del derecho espanol» já não é suficiente. Como seu suplemente é de recorrer à revista histórica «Hispania», mas também a "Recerques - Historia, economia, cultura», aparecidas em $1973 \mathrm{em}$ Barcelona; também à publicação de ciência económica «Moneda y credito» e às revistas de ciências sociais «Sistema» (para Espanha) e "Análise Social» e «Revista critica de ciencias sociais» (para Portugal). Mas não se deve ficar pelas fronteiras nacionais. Os tantas vezes citados "Quaderni fiorentini» parece terem assumido um lugar de afirmação da nova história do direito, o que os torna de leitura obrigatória. Isto é também válido, e de forma muito especial, para a revista "Annales - Economies -- Societés - Civilisations», a quem compete, como a nenhuma outra revista europeia, um lugar de vanguarda no campo das ciências históricas. Assim se fará simultaneamente justiça aos mais recentes desenvolvimentos da história jurídica espanhola e portuguesa, cujos representantes mais progressivos percorreram já este caminho.

JohanNes-Michael Scholz 